\title{
The Upper Rim Functionalized Calixarene Ketocyanines: Synthesis, Structure and Fluorescence Properties
}

\author{
Yuriy Matvieiev, ${ }^{a}$ Andrii Kulinich, ${ }^{\text {a }}$ Aleksey Ryabitskii, ${ }^{a}$ Svitlana Shishkina, ${ }^{\text {b }}$ \\ Oleg Shishkin, ${ }^{\mathrm{b}}$ Vasyl Pivovarenko, ${ }^{\mathrm{c}}$ and Vitaly Kalchenko ${ }^{\mathrm{a}}$ \\ anstitute of Organic Chemistry, National Academy of Sciences of Ukraine, 02660 Kyiv, Ukraine \\ 'Institute for Single Crystals, National Academy of Sciences of Ukraine, 61001 Kharkiv, Ukraine \\ ${ }^{\mathrm{c}}$ Chemical Faculty, Taras Shevchenko National University of Kyiv, 01601 Kyiv, Ukraine \\ ${ }^{\circledR}$ Corresponding author E-mail: vik@ioch.kiev.ua
}

The calix[4]arene ketocyanine receptors bearing nitro-, amino- or urea moiety at the wide macrocycle rim were elaborated. Their molecular structures, UV-Vis absorption and fluorescence properties were studied. The estimated solvatofluorochromism levels and quantum yield values demonstrate clearly a possibility of control of the fluorescence colour and intensity by varying the nature of the analyte bound in the proximity of the fluorophore ketocyanine unit.

Keywords: Calix[4]arene, ketocyanine, Knoevenagel reaction, X-ray diffraction study, solvatochromism.

\section{Функционализированные по верхнему ободу каликсарен- кетоцианины: синтез, структура и флуоресцентные свойства}

\author{
Ю. Матвеев, ${ }_{1}{ }^{a}$ А. Кулинич, ${ }^{a}$ А. Рябицкий, ${ }^{a}$ C. Шишкина, ${ }_{1}{ }^{b}$ О. Шишкин, ${ }^{b}$ \\ В. Пивоваренко, ${ }^{\text {c }}$ В. Кальченко ${ }^{\mathrm{a}}$
}

анститут органической химии НАН Украины, 02660 Киев, Украина

${ }^{\mathrm{b}}$ Институт монокристаллов НАН Украинь, 61001 Харьков, Украина

'Химический факультет Киевского наџионального университета им. Тараса Шевченко, 01601 Киев, Украина

@E-mail:vik@ioch.kiev.ua

\begin{abstract}
Реакцией Кновенагеля легкодоступного нитроформилдипропоксикаликс[4]арена с $\alpha, \beta$-ненасыщенныли циклопентанонами в среде ионной жидкости диметиламмонийдиметилкарбамата получень каликс[4]аренкетоцианины, содержащче нитро-, амино- или мочевинную группу на иироком (верхнем) ободе макроцикла. Методами ЯМР спектроскопии и рентгеноструктурного анализа установлена их конусообразная структура в растворах и кристаллическом состоянии. В кристаллической фазе молекула каликс[4]арен-кетоцианина существует как центросимметричный димер, образованный за счет межмолекулярной цуиклизации углерод-углеродных связей кетоичининовых фрагментов. Исследованы электронные спектры поглощения и флуоресиенции полученных соединений. Объемы сольватофлуорохромии и значения квантовых выходов флуоресиенции полученных соединений демонстрируют возможность контроля иявта и интенсивности их флуоресиенции путем варьирования характера аналита, связанного супрамолекулярньми взаимодействиями типа гость-хозяин в непосредственной близости от флуорофорного кетоциианинового фрагмента.
\end{abstract}

Ключевые слова: Каликс[4]арены, кетоцианины, реакция Кновенагеля, рентгеноструктурный анализ, сольватохромия. 


\section{Introduction}

Fluorescent probes - organic molecules with an analyte receptor and fluorophore group - is a powerful tool to study the structure and function of biomolecules, cell organelles and cells in general. ${ }^{[1-3]}$ Therefore, design of high sensitive and selective sensors for small organic molecules is certainly a topic of great interest in modern organic chemistry. The development of ultra-sensitive detection devices has a strong impact on bioanalysis, as the sensitivity of biochemical assays could be dramatically increased. ${ }^{[4]}$

According to the definition approved by IUPAC "a chemical sensor is a device that transforms chemical information, ranging from the concentration of a specific sample component to total composition analysis, into an analytically useful signal". In a narrow sense, the sensor is a molecule, which is able to bind selectively the target molecule (or supra-molecular structure, living cell) and provide information about this binding. The main issue in the design of any effective chemosensor is the association of a selective molecular recognition event with a physical signal highly sensitive to its occurrence. The considerable interest to such devices is caused by relatively simple $\mathrm{UV}-\mathrm{Vis}$ or fluorescence technique and their superior sensitivity. ${ }^{[5-8]}$

Calixarenes due to their distinctive tuneable cavity and its amenability to decoration, through regio- and stereoselective control, have resulted in their widespread utilization as a host molecules in supramolecular chemistry. ${ }^{[9,10]}$ They show unique ability to recognize and selectively bind in the Host-Guest supramolecular complexes ions, organic and biomolecules ${ }^{[11-14]}$ that in turn makes them promising receptors to create fluorescent probes.

In this paper, we report the synthesis as well as structural and UV-Vis-fluorescent studies of calix[4]arenes bearing ketocyanine fluorophore groups at the upper macrocycle rim and nitro group or urea fragments in distal position to the ketocyanine fluorophore moiety.

\section{Experimental}

All the reactions were carried out in freshly distilled anhydrous solvents. Melting points were determined on a Boetius apparatus and are uncorrected. Column chromatography was carried out using Acros Organics silica gel $(0.04-0.06 \mathrm{~mm}$, pore diameter $6 \mathrm{~nm})$. ${ }^{1} \mathrm{H}$ and ${ }^{13} \mathrm{C}$ NMR spectra were recorded on Varian GEMINI 2000 spectrometer with frequency 400 and $100 \mathrm{MHz}$, respectively (TMS as an internal standard). ${ }^{1} \mathrm{H}-{ }^{1} \mathrm{H}$ COSY spectra were acquired into 2048 (F2) and 512 (F1) time-domain data matrix. Mass-spectra were recorded on Agilent 1100 LS/MSD spectrometer. The UV/ Vis and fluorescence spectra were recorded with Shimadzu UV3100 spectrophotometer and Solar-CM2203 spectrofluorometer (Belarus) correspondingly. All spectra were registered at $20{ }^{\circ} \mathrm{C}$ with sampling interval of $1 \mathrm{~nm}$, slit width of $2 \mathrm{~nm}$ (the same widths for the incident beam and fluorescent light). The UV-Vis spectra were registered at concentrations $10^{-5}-2 \cdot 10^{-5} \mathrm{M}$ in $1 \mathrm{~cm}$ quartz cuvettes. For fluorescent measurements these solutions were further dissolved so that their optical densities at the absorption maxima did not exceed 0.1 (to avoid inner filter effects). Solvent for spectral measurements were purified according to the methods given in ${ }^{[15]}$ and not degassed.

The X-ray diffraction data were collected on an Xcalibur-3 diffractometer (graphite monochromated $\mathrm{MoK} \alpha$ radiation, $\mathrm{CCD}$ detector). The structures were solved by direct methods using the SHELXTL package. ${ }^{[16]}$ The positions of the hydrogen atoms were located from electron density difference maps and refined using the "riding" model with $\mathrm{U}_{\text {iso }}=\mathrm{nU}$ eq for the carrier atom $(\mathrm{n}=1.5$ for methyl and $n=1.2$ for other hydrogen atoms). The hydrogen atoms of the hydroxyl groups are refined using isotropic approximation. The final atomic coordinates, and crystallographic data have been deposited with the Cambridge Crystallographic Data Centre, 12 Union Road, CB2 1EZ, UK (fax: +44-1223-336033; e-mail: deposit@ccdc.cam.ac.uk) and are available on request quoting the deposition numbers.

Structures of molecules 1-5 are shown in Scheme 1. The synthetic procedures for $\mathbf{1}$ and $\mathbf{2}$ are described elsewhere. ${ }^{[17]}$

3a: Yield $87 \%$. M.p. $>300{ }^{\circ} \mathrm{C}(\mathrm{dec}) .{ }^{1} \mathrm{H}$ NMR $\left(\mathrm{CDCl}_{3}\right)$ $\delta_{\mathrm{H}}$ ppm: $1.33\left(6 \mathrm{H}, \mathrm{t} J=7.3 \mathrm{~Hz}, \mathrm{OCH}_{2} \mathrm{CH}_{2} \mathrm{CH}_{3}\right), 2.10(4 \mathrm{H}, \mathrm{m}$, $\left.\mathrm{OCH}_{2} \mathrm{CH}_{2} \mathrm{CH}_{3}\right), 3.04\left(6 \mathrm{H}, \mathrm{s}, \mathrm{N}\left(\mathrm{CH}_{3}\right)_{2}\right), 3.10\left(4 \mathrm{H}\right.$, br.s, $\mathrm{CH}_{2} \mathrm{CH}_{2}$ of cyclopentanone), 3.46 and $3.49\left(4 \mathrm{H}\right.$, two overlapped $\mathrm{d} J^{2}=13.4 \mathrm{~Hz}$, Ar- $\mathrm{CH}_{2}$-eq.), 4.02 (4H, m, $\left.\mathrm{OCH}_{2} \mathrm{CH}_{2} \mathrm{CH}_{3}\right), 4.30$ and $4.32(4 \mathrm{H}$, two

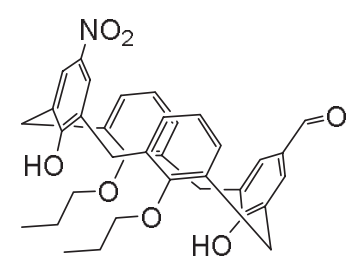

1

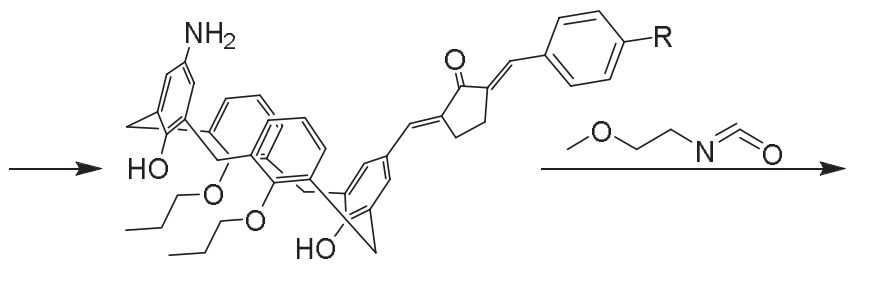

$4 a, b$

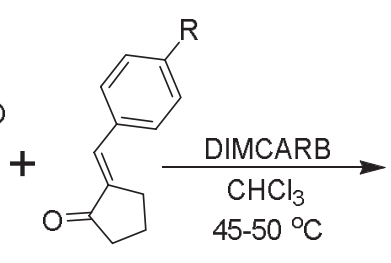

$\mathbf{2 a , b}$

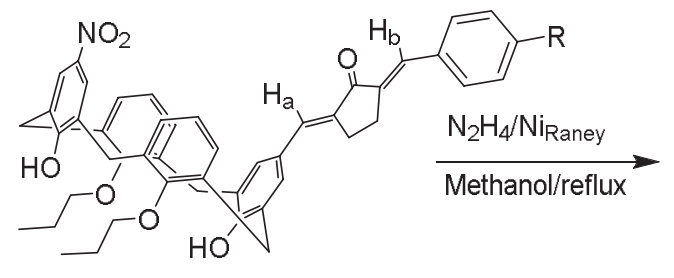

3a,b

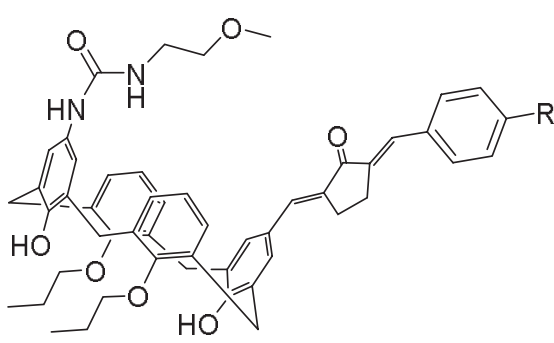

$5 a, b$
$\mathrm{R}=\mathrm{NMe}_{2}(\mathrm{a}) ; \mathrm{OMe}(\mathrm{b})$

Scheme 1. Synthesis of calixarene-based ketocyanines. 
overlapped d $\mathcal{J}^{2}=13.4 \mathrm{~Hz}, \mathrm{Ar}-\mathrm{CH}_{2}$-ax.), $6.74(2 \mathrm{H}, \mathrm{d} J=8.7 \mathrm{~Hz}, \mathrm{ArH})$, $6.83(2 \mathrm{H}, \mathrm{t} J=7.75 \mathrm{~Hz}, \mathrm{ArH}), 6.98$ (4H, m, ArH), 7.36 (2H, s, ArH), $7.48(1 \mathrm{H}$, br.s, $-\mathrm{CH}=), 7.52$ and $7.55(3 \mathrm{H}$, two overlapped br.s, $2 \mathrm{ArH}+-\mathrm{CH}=), 8.04(2 \mathrm{H}, \mathrm{s}, \mathrm{ArH}), 8.73(1 \mathrm{H}, \mathrm{s}, \mathrm{OH}), 9.52(1 \mathrm{H}, \mathrm{s}$, $\mathrm{OH}) .{ }^{13} \mathrm{C} \mathrm{NMR}\left(\mathrm{CDCl}_{3}\right) \delta_{\mathrm{C}} \mathrm{ppm}: 195.72,159.62,151.55,150.69$, $134.88,134.07,132.99,132.85,132.81,132.52,131.60,131.41$, $129.50,129.00,128.40,128.11,125.60,124.40,112.10,111.81$, 78.62, 40.19, 31.62, 31.42, 26.79, 23.60, 11.05. LC-MS: $m / z=779.4$ $[\mathrm{M}]^{+}$. Found: C 76.32, H 6.54, N $3.48 \% . \mathrm{C}_{49} \mathrm{H}_{50} \mathrm{~N}_{2} \mathrm{O}_{7}$ requires $\mathrm{C}$ 75.56, H 6.47, N 3.60 .

The X-ray diffraction study of 5-nitro-17-\{(E)-[(3E)3-(4-dimethylaminobenzylidene)-2-oxocyclopentylidene] methyl\}-26,28-dihydroxy-25,27-dipropoxycalix[4]arene, $3 a$ (the deposition number CCDC 1025172). The colourless crystals of 3a $\mathrm{C}_{49} \mathrm{H}_{50} \mathrm{O}_{7} \mathrm{~N}_{2} \cdot \mathrm{CHCl}_{3}$ are monoclinic. At $100 \mathrm{~K}$ : $\mathrm{a}=22.138(1)$, $\mathrm{b}=10.5509(5), \quad \mathrm{c}=19.520(1) \quad \AA, \quad \beta=104.794(5)^{\circ}, \quad \mathrm{V}=4408.3(4)$ $\AA^{3}, \mathrm{Mr}=898.28, \mathrm{Z}=4$, space group $\mathrm{P} 2 / \mathrm{c}, \mathrm{d}_{\text {calc }}=1.353 \mathrm{~g} / \mathrm{cm}^{3}, \mu$ $(\mathrm{MoK} \alpha)=0.264 \mathrm{~mm}^{-1}, \mathrm{~F}(000)=1888$. Intensities of 33690 reflections (12849 independent, $\left.\mathrm{R}_{\mathrm{int}}=0.085\right)$ were measured ( $\omega$-scaning, $2 \Theta \max =60^{\circ}$ ). Full-matrix least-squares refinement of the structure against $\mathrm{F}^{2}$ in anisotropic approximation for non-hydrogen atoms using 12811 reflections converged to $\mathrm{wR}_{2}=0.173\left(\mathrm{R}_{1}=0.074\right.$ for 6897 reflections with $\mathrm{F}>4 \sigma(\mathrm{F}), \mathrm{S}=0.987)$.

3b: Yield $69 \%$. M.p. $303-306{ }^{\circ} \mathrm{C}$. ${ }^{1} \mathrm{H} \mathrm{NMR}\left(\mathrm{CDCl}_{3}\right) \delta_{\mathrm{H}}$ ppm: $1.32\left(6 \mathrm{H}, \mathrm{t} J=7.3 \mathrm{~Hz}, \mathrm{OCH}_{2} \mathrm{CH}_{2} \mathrm{CH}_{3}\right), 2.08\left(\mathrm{~m}, 4 \mathrm{H}, \mathrm{OCH}_{2} \mathrm{CH}_{2}-\right.$ $\left.\mathrm{CH}_{3}\right), 3.08$ (4H, br.s, $\mathrm{CH}_{2} \mathrm{CH}_{2}$ of cyclopentanone), 3.47 and 3.50 (4H, two overlapped d $J=13.2 \mathrm{~Hz}, \mathrm{Ar}-\mathrm{CH}_{2}$-eq.), $3.84\left(3 \mathrm{H}, \mathrm{s}, \mathrm{OCH}_{3}\right)$, $3.99\left(4 \mathrm{H}, \mathrm{m} J=6.3 \mathrm{~Hz}, \mathrm{OCH}_{2} \mathrm{CH}_{2} \mathrm{CH}_{3}\right), 4.31$ and 4.32 (4H, two overlapped d $\mathcal{J}^{2}=13.2 \mathrm{~Hz}, \mathrm{Ar}^{2} \mathrm{CH}_{2}$-ax.), 6.83 ( $\left.2 \mathrm{H}, \mathrm{t} J=7.6 \mathrm{~Hz}, \mathrm{ArH}\right)$, $6.98(6 \mathrm{H}, \mathrm{m}, \mathrm{ArH}), 7.37$ (2H, s, ArH), 7.52 (1H, br.s, $-\mathrm{CH}=), 7.55$ and $7.57(3 \mathrm{H}$, overlapped br.s and d $J=7.6 \mathrm{~Hz},-\mathrm{CH}=+2 \mathrm{ArH}$,), $8.04(2 \mathrm{H}, \mathrm{s}, \mathrm{ArH}), 8.79(1 \mathrm{H}, \mathrm{s}, \mathrm{OH}), 9.52(1 \mathrm{H}, \mathrm{s}, \mathrm{OH}) .{ }^{13} \mathrm{C} \mathrm{NMR}$ $\left(\mathrm{CDCl}_{3}\right) \delta_{\mathrm{C}}$ ppm: $195.78,160.23,159.58,154.86,151.54,139.54$, $135.32,134.17,133.81,132.91,132.76,132.26,131.61,131.54$, $129.44,129.01,128.73,128.37,128.19,127.29,125.57,124.37$, $114.17,78.61,55.38,31.60,31.40,26.73,26.64,23.58,11.03$. LCMS: $m / z=766.4[\mathrm{M}]^{+}$. Found: C 76.02, H 6.24, N $1.88 \% . \mathrm{C}_{48} \mathrm{H}_{47} \mathrm{NO}_{8}$ requires $\mathrm{C} 75.27, \mathrm{H} 6.19, \mathrm{~N} 1.83$.

The X-ray diffraction study of 5-nitro-17-\{(E)-[(3E)-3(4-methoxybenzylidene)-2-oxocyclopentylidene]methyl\}-26,28dihydroxy-25,27-dipropoxy-calix[4]arene, $3 \boldsymbol{b}$ (CCDC 1025173). The colourless crystals of $3 \mathbf{b} 2 \mathrm{C}_{48} \mathrm{H}_{47} \mathrm{O}_{8} \mathrm{~N} \cdot \mathrm{CH}_{3} \mathrm{OH} \cdot 4 \mathrm{H}_{2} \mathrm{O}$ are monoclinic. At $100 \mathrm{~K}: \mathrm{a}=42.215(4), \mathrm{b}=10.2820(7), \mathrm{c}=20.249$ (2) $\AA$, $\beta=99.321(9)^{\circ}, V=8673(1) \AA^{3}, M r=1635.84, Z=4$, space group $C 2 / c$, $\mathrm{d}_{\text {calc }}=1.253 \mathrm{~g} / \mathrm{cm}^{3}, \mu(\mathrm{MoK} \alpha)=0.088 \mathrm{~mm}^{-1}, \mathrm{~F}(000)=3480$. Intensities of 27822 reflections ( 7618 independent, $\mathrm{R}_{\mathrm{int}}=0.125$ ) were measured ( $\omega$-scaning, $2 \Theta \max =50^{\circ}$ ). The restriction on the $\mathrm{C}-\mathrm{O}$ bond length $(1.41 \AA)$ for the solvate methanol molecule was applied. Fullmatrix least-squares refinement of the structure against $\mathrm{F}^{2}$ in anisotropic approximation for non-hydrogen atoms using 7579 reflections converged to $\mathrm{wR}_{2}=0.210\left(\mathrm{R}_{1}=0.080\right.$ for 3463 reflections with $\mathrm{F}>4 \sigma(\mathrm{F}), \mathrm{S}=0.927)$.

General method for synthesis of 5-N-(2-methoxyethyl)- $N$ 'urea-17-\{(E)-[(3E)-3-(4-dimethylamino(methoxy)benzyli-dene)-2oxocyclo-pentylidene]methyl\}-25,27-dipropoxy-26,28-dihydroxycalix[4]arenes, $\mathbf{5 a}, \boldsymbol{b}$.

To a suspension of $0.5 \mathrm{mmol}$ of nitrocalixarene $\mathbf{3 a}, \mathbf{b}$ in $20 \mathrm{ml}$ of methanol, $1.5 \mathrm{ml}$ of $100 \%$ hydrazine hydrate $(30 \mathrm{mmol})$ was added. The reaction mixture was heated to $70{ }^{\circ} \mathrm{C}$ and $0.1 \mathrm{ml}$ of $50 \%$ aqueous suspension of Raney nickel was added. After stirring at $70{ }^{\circ} \mathrm{C}$ for $5 \mathrm{hrs}$ reaction mixture was cooled to room temperature and $15 \mathrm{ml}$ of chloroform was added. The solution was filtered off through silica gel. Evaporation of solvent resulted in aminocalixarenes $\mathbf{4 a}, \mathbf{b}$ as yellow solids.

To a solution of $0.4 \mathrm{mmol}$ aminocalixarene $4 \mathbf{a}, \mathbf{b}$ in $10 \mathrm{ml}$ of chloroform $0.4 \mathrm{mmol}$ of 2-methoxyethyl isocyanate in $2 \mathrm{ml}$ of chloroform was added dropwise. Reaction mixture was stirred at room temperature for 12 hours. The solvent was removed under reduced pressure and the residue - compounds $\mathbf{5 a}, \mathbf{b}$ - was purified by column chromatography (eluent - ethyl acetate).

5a: Yield 68\%. M.p. $>320{ }^{\circ} \mathrm{C}$ (dec.). ${ }^{1} \mathrm{H} \mathrm{NMR}\left(\mathrm{CDCl}_{3}\right) \delta_{\mathrm{H}} \mathrm{ppm}$ : $1.32\left(6 \mathrm{H}, \mathrm{t} J=7.3 \mathrm{~Hz}, \mathrm{OCH}_{2} \mathrm{CH}_{2} \mathrm{CH}_{3}\right), 2.08\left(4 \mathrm{H}, \mathrm{m}, \mathrm{OCH}_{2} \mathrm{CH}_{2} \mathrm{CH}_{3}\right)$, $3.04\left(6 \mathrm{H}, \mathrm{s}, \mathrm{N}\left(\mathrm{CH}_{3}\right)_{2}\right), 3.09$ (4H, br.s, $\mathrm{CH}_{2} \mathrm{CH}_{2}$ of cyclopentanone), $3.32\left(3 \mathrm{H}, \mathrm{s}, \mathrm{OCH}_{3}\right), 3.38$ and $3.43(8 \mathrm{H}$, two overlapped $\mathrm{m}$, $\mathrm{CH}_{2} \mathrm{CH}_{2}+\mathrm{Ar}-\mathrm{CH}_{2}$-eq.), $3.99\left(4 \mathrm{H}, \mathrm{t} J=6.1 \mathrm{~Hz}, \mathrm{OCH}_{2} \mathrm{CH}_{2} \mathrm{CH}_{3}\right), 4.31$ and $4.32\left(4 \mathrm{H}\right.$, two overlapped d $\Omega^{2}=12.5 \mathrm{~Hz}, \mathrm{Ar}_{-} \mathrm{CH}_{2}-\mathrm{ax}$.), $4.95(1 \mathrm{H}$, $\mathrm{t} J=5.4 \mathrm{~Hz}, \mathrm{NH}), 6.14(1 \mathrm{H}, \mathrm{s}, \mathrm{NH}), 6.73(2 \mathrm{H}, \mathrm{d} J=8.8 \mathrm{~Hz}, \mathrm{ArH}), 6.78$ $(2 \mathrm{H}, \mathrm{t} J=7.6 \mathrm{~Hz}, \mathrm{ArH}), 6.95$ (6H, m, ArH), 7.35 (s, 2H, ArH), 7.47 (br.s, $1 \mathrm{H},-\mathrm{CH}=), 7.52$ and $7.54(3 \mathrm{H}$, overlapped br.s and $\mathrm{d},-\mathrm{CH}=$ $+2 \mathrm{ArH}), 8.40(1 \mathrm{H}, \mathrm{s}, \mathrm{OH}), 8.86(1 \mathrm{H}, \mathrm{s}, \mathrm{OH}) .{ }^{13} \mathrm{C} \mathrm{NMR}\left(\mathrm{CDCl}_{3}\right)$ $\delta_{\mathrm{C}}$ ppm: $195.98,156.84,154.92,151.77,134.78,134.10,133.12$, $132.97,132.59,131.50,129.02,128.93,128.60,128.42,127.47$, $125.45,124.48,111.85,78.48,71.95,58.72,40.15,31.59,31.36$, 30.96, 26.71, 23.52, 10.97. LC-MS: $m / z=852.5[\mathrm{M}+\mathrm{H}]^{+}$. Found: $\mathrm{C}$ 75.02, $\mathrm{H} 6.94, \mathrm{~N} 4.88 \% . \mathrm{C}_{53} \mathrm{H}_{59} \mathrm{~N}_{3} \mathrm{O}_{7}$ requires $\mathrm{C} 74.89, \mathrm{H} 7.00$, N 4.94 .

5b: Yield $88 \%$. M.p. $>260{ }^{\circ} \mathrm{C}$ (dec.). ${ }^{1} \mathrm{H} \mathrm{NMR}\left(\mathrm{CDCl}_{3}\right) \delta_{\mathrm{H}}$ ppm: $1.32\left(6 \mathrm{H}, \mathrm{t} J=7.3 \mathrm{~Hz}, \mathrm{OCH}_{2} \mathrm{CH}_{2} \mathrm{CH}_{3}\right), 2.07\left(4 \mathrm{H}, \mathrm{m}, \mathrm{OCH}_{2} \mathrm{CH}_{2} \mathrm{CH}_{3}\right)$, 3.11 (4H, br.s, $\mathrm{CH}_{2} \mathrm{CH}_{2}$ of cyclopentanone), $3.31\left(3 \mathrm{H}, \mathrm{s}, \mathrm{OCH}_{3}\right), 3.36$ and $3.42\left(8 \mathrm{H}\right.$, two overlapped $\mathrm{m}, \mathrm{CH}_{2} \mathrm{CH}_{2}+\mathrm{Ar}_{-} \mathrm{CH}_{2}$-eq. $), 3.84(3 \mathrm{H}$, $\left.\mathrm{s}, \mathrm{OCH}_{3}\right), 3.99\left(\mathrm{t}, 4 \mathrm{H}, J=6.1 \mathrm{~Hz}, \mathrm{OCH}_{2} \mathrm{CH}_{2} \mathrm{CH}_{3}\right), 4.29$ and $4.32(4 \mathrm{H}$, two overlapped d $\Omega^{2}=13.2 \mathrm{~Hz}, \mathrm{Ar}-\mathrm{CH}_{2}$-ax.), $5.07(1 \mathrm{H}, \mathrm{t} J=5.4 \mathrm{~Hz}$, $\left.\mathrm{NHCH}_{2}\right), 6.36(1 \mathrm{H}, \mathrm{s}, \mathrm{ArNH}), 6.76(2 \mathrm{H}, \mathrm{t} J=7.5 \mathrm{~Hz}, \mathrm{ArH}), 6.95(8 \mathrm{H}$, $\mathrm{m}, \mathrm{ArH}), 7.36(2 \mathrm{H}, \mathrm{s}, \mathrm{ArH}), 7.52(1 \mathrm{H}$, br.s, $-\mathrm{CH}=), 7.54$ and 7.56 (3H, overlapped br.s and d, $-\mathrm{CH}=+2 \mathrm{ArH}), 8.36(1 \mathrm{H}, \mathrm{s}, \mathrm{OH}), 8.91$ $(1 \mathrm{H}, \mathrm{s}, \mathrm{OH}) .{ }^{13} \mathrm{C} \mathrm{NMR}\left(\mathrm{CDCl}_{3}\right) \delta_{\mathrm{C}} \mathrm{ppm}: 196.10,160.34,155.23$, $151.76,150.92,135.47,134.16,134.07,133.15,132.86,132.36$, $131.67,129.07,128.94,128.84,128.81,128.76,128.52,127.19$, $125.43,124.17,114.23,78.47,71.97,58.70,55.37,40.12,31.58$, $31.37,26.64,23.51,10.96$. IR (KBr) $v_{\max } \mathrm{cm}^{-1}: v_{\mathrm{NH}}=3260-3420$, $v_{\mathrm{OH}}=2940, v_{\mathrm{C}=\mathrm{O}}=1655$, 1595. Found: C 75.08, H 6.84, N $3.38 \%$. $\mathrm{C}_{52} \mathrm{H}_{56} \mathrm{~N}_{2} \mathrm{O}_{8}$ requires C 74.62, H 6.74, N 3.35.

The X-ray diffraction study of 5-N-(2-methoxyethyl)-N' urea-17-\{(E)-[(3E)-3-(4-methoxybenzylidene)-2-oxocyclopentylidene]methyl\}-25,27-dipropoxy-26,28-dihydroxycalix [4] arene, $5 \boldsymbol{b}$ (CCDC 1025174). The colourless crystals of $\mathbf{5 b}$ $4 \mathrm{C}_{104} \mathrm{H}_{112} \mathrm{O}_{16} \mathrm{~N}_{4} \cdot 2 \mathrm{CH}_{3} \mathrm{OH} \cdot 4 \mathrm{H}_{2} \mathrm{O}$ are orthorhombic. At $120 \mathrm{~K}$ : $\mathrm{a}=49.612(9), \quad \mathrm{b}=9.668(2), \quad \mathrm{c}=19.614(3) \quad \AA, \quad \mathrm{V}=9408(3) \quad \AA^{3}$, $\mathrm{Mr}=1715.98, \mathrm{Z}=4$, space group Pbcn, $\mathrm{d}_{\text {calc }}=1.212 \mathrm{~g} / \mathrm{cm}^{3}, \mu$ $(\mathrm{MoK} \alpha)=0.083 \mathrm{~mm}^{-1}, \mathrm{~F}(000)=3652$. Intensities of 78208 reflections (8294 independent, $\mathrm{R}_{\mathrm{int}}=0.145$ ) were measured ( $\omega$-scaning, $\left.2 \Theta \max =50^{\circ}\right)$. The restrictions on the $\mathrm{Csp}^{3}-\mathrm{O}$ and $\mathrm{Csp}^{3}-\mathrm{Csp}^{3}$ bond lengths ( $1.43 \AA$ and $1.54 \AA$, respectively) for the disordered propyl group were applied. The solvate methanol molecule and disordered over some positions water molecule are refined in isotropic approximation without hydrogen atoms. Full-matrix least-squares refinement of the structure against $\mathrm{F}^{2}$ in anisotropic approximation for non-hydrogen atoms using 8125 reflections converged to $w_{2}=0.212\left(R_{1}=0.084\right.$ for 2717 reflections with $\left.F>4 \sigma(F), S=0.846\right)$.

\section{Results and Discussion}

To introduce the ketocyanine moiety to the macrocyclic backbone we employed the Knoevenagel reaction between readily available nitroformyl propoxycalix[4]arene $\mathbf{1}^{[18]}$ and $\alpha, \beta$-unsaturated cyclopentanones $\mathbf{2} \mathbf{a}, \mathbf{b}^{[19]}$ in the presence of dimethylammonium dimethylcarbamate (DIMCARB) ${ }^{[17,20]}$ as a co-solvent and catalyst (Scheme 1).

In the ${ }^{1} \mathrm{H}$ NMR spectra of compounds $\mathbf{3 a}, \mathbf{b}$, the $\mathrm{AB}$ spin system of the axial and equatorial $\mathrm{H}$-atoms of the $\mathrm{ArCH}_{2} \mathrm{Ar}$ methylene groups appeared as two doublets at $\delta 4.33$ and $\delta 4.31\left(\mathrm{H}_{\mathrm{ax}}\right)$ and a multiplet at $\delta 3.41\left(\mathrm{H}_{\mathrm{eq}}\right)$ with ${ }^{2} J_{\mathrm{HH}} 12.8-$ 13.4 Hz. The chemical shift difference between $\mathrm{H}_{\mathrm{ax}}$ and $\mathrm{H}_{\mathrm{eq}}$ 
of about 0.9 ppm reflects the flattened cone conformation of $\mathbf{3 a}, \mathbf{b}$ in solution. ${ }^{[21]}{ }^{13} \mathrm{C}$ NMR resonances for the carbons of the methylene bridges appeared at $\delta 31.31-31.48 \mathrm{ppm}$, which reflects the syn orientation of the adjacent phenolic rings in the cone conformation. ${ }^{[22]}$

Diffraction quality crystals of $\mathbf{3 a}, \mathbf{b}$ were grown from chloroform-methanol mixtures. The X-ray diffraction study showed that the molecules existed in $E, E$-form in the solid state. Macrocycles 3a and $\mathbf{3 b}$ adopt a cone conformation (Figure 1). The distance between centres of opposite benzene rings $(6.65 \AA$ and $6.70 \AA$ for $3 \mathbf{a}$ and $6.89 \AA$ and $6.46 \AA$ for 3b) and angles between their planes $\left(50.2^{\circ}\right.$ and $66.4^{\circ}$ for $\mathbf{3 a}$ and $72.9^{\circ}$ and $46.0^{\circ}$ for $\mathbf{3 b}$ ) are close enough. Conjugation of the aromatic $\pi$-system with the ketocyanine fragment is revealed in both compounds. The nitro-group is coplanar to the aromatic ring.

We have used calixarene ketocyanines 3a,b for the synthesis of corresponding urea derivatives. Calixarenes decorated with urea fragment are well known as anion receptors $^{[23]}$ and therefore are of particular interest in their binding and sensing. Also anion-receptor interactions underlie many catalytic processes in vivo. ${ }^{[24,25]}$

Reduction of nitrocalixarene ketocyanines $\mathbf{3 a}, \mathbf{b}$ was performed with hydrazine hydrate in the presence of Raney nickel under reflux in methanol forming aminocalixarenes 4a,b. Amines $4 \mathbf{a}, \mathbf{b}$ are unstable in the open air compounds and were treated with isocyanate without isolation. ${ }^{[26]}$ Reaction of aminocalixarenes $\mathbf{4 a}, \mathbf{b}$ with equimolar quantity of 2-methoxyethyl isocyanate proceeds at room temperature in chloroform giving the corresponding urea derivatives $\mathbf{5 a}, \mathbf{b}$ with yields $68 \%$ and $88 \%$, respectively (Scheme 1).

In the ${ }^{1} \mathrm{H}$ NMR spectra of compounds 5a,b (Figure 2) recorded in $\mathrm{CDCl}_{3}$, the signals of equatorial $\mathrm{ArCH}_{2} \mathrm{Ar}$ protons are revealed as two multiplets in the field 3.32
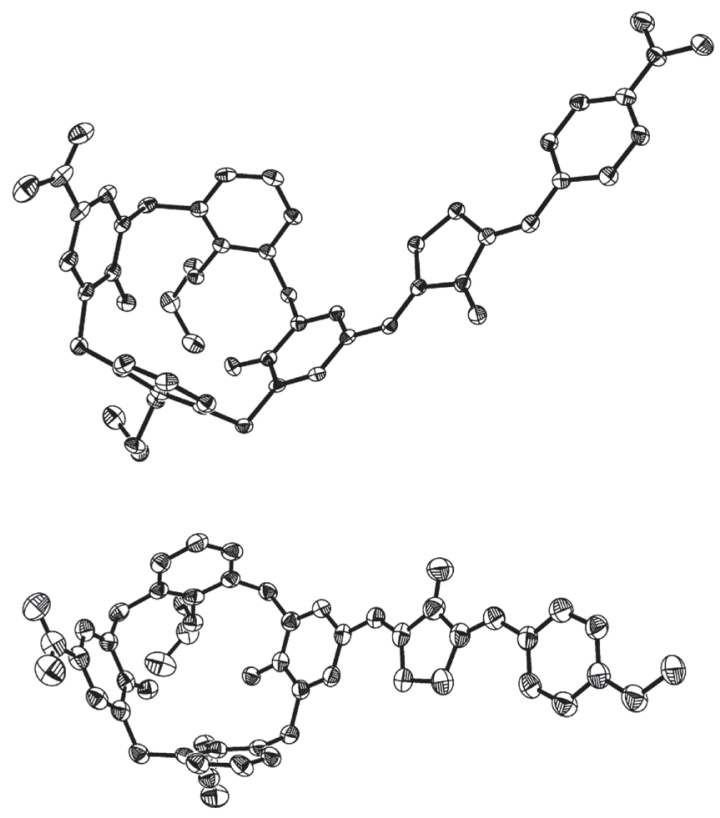

Figure 1. X-ray crystal structures of the compounds 3a (above) and $\mathbf{3 b}$ (down); $\mathrm{H}$-atoms are omitted for clarity.

The E,E-conformations are clearly shown.

Thermal ellipsoids are shown at the $50 \%$ probability level.
$3.43 \mathrm{ppm}$ which strongly overlapped with the signals of $\mathrm{CH}_{2} \mathrm{CH}_{2}$ residue of urea moiety. The axial $\mathrm{ArCH}_{2} \mathrm{Ar}$ protons appeared as two doublets at 4.29 and $4.32 \mathrm{ppm}$. The $\mathrm{NH}$ protons of urea fragment in $\mathbf{5 a}$ and $\mathbf{5 b}$ molecules were observed as triplets at 4.95 and $5.07 \mathrm{ppm}$ with ${ }^{3} J_{\mathrm{HH}} 5.4 \mathrm{~Hz}$ and singlets at 6.14 and $6.36 \mathrm{ppm}$, respectively. The broad singlet at $3.10 \mathrm{ppm}$ corresponds to cyclopentanone ring protons. The signals of hydroxyl protons are revealed as two singlets in the field $8.3-8.9 \mathrm{ppm} .{ }^{13} \mathrm{C} \mathrm{NMR}$ resonances for the carbons of the methylene bridges appeared at $\delta 30.96-$ $31.58 \mathrm{ppm}$, which reflects the syn orientation of the adjacent phenolic rings in the cone conformation. In IR spectra (KBr) of calixarenes $\mathbf{5 a}, \mathbf{b}$ there are characteristic bands in regions $3260-3420 \mathrm{~cm}^{-1}\left(v_{\mathrm{NH}}\right), 2940 \mathrm{~cm}^{-1}\left(v_{\mathrm{OH}}\right), 1655,1595 \mathrm{~cm}^{-1}$ $\left(v_{\mathrm{C}=\mathrm{O}}\right)$.

Unexpected results were obtained by X-ray study of single crystal $\mathbf{5 b}$ obtained from ethyl acetate solution. According to the spectral data the compound $\mathbf{5 b}$ exists as mono molecule in the solution. But in the crystal phase there was observed a centrosymmetrical molecule formed due to cyclization of carbon-carbon double bounds of ketocyanine moieties of two neighbouring $\mathbf{5 b}$ molecules (Figure 3). The presence of conjugated $\pi$-system of ketocyanine fragment and relative position of neighbouring molecules $\mathbf{5 b}$ create conditions for stacking interaction between them. Earlier ${ }^{[27]}$ the possibility of the photo-dimerization of molecules in crystal phase under such conditions was shown. The dimer of $\mathbf{5 b}$ is located in special position on the 2-fold axis which passes through the centre of formed cyclobutane fragment. It can be assumed that the dimerization of $\mathbf{5 b}$ results in the deformation of its cone conformation (Figure 3). The distance between centres of opposite benzene rings (7.30 $\AA$ and $5.93 \AA$ ) and angles between their planes $\left(87.1^{\circ}\right.$ and $28.1^{\circ}$ ) are rather different in contrast to $\mathbf{3} \mathbf{a}$ and $\mathbf{3 b}$.

To estimate the influence of the calixarene framework on the absorption and fluorescence properties of $\mathbf{3} \mathbf{a}, \mathbf{b}$ and $\mathbf{5 a}, \mathbf{b}$ the model compound $\mathbf{6}^{[17]}$ which can be considered as isolated ketocyanine fluorophore of $\mathbf{3 b}$, was used for comparison (Scheme 2).

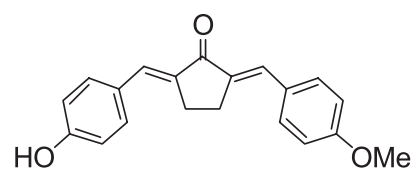

Scheme 2. The model compound 6 .

The UV-Vis and steady state fluorescence spectra of compounds $\mathbf{3 a}, \mathbf{b}, \mathbf{5 a}, \mathbf{b}$, and $\mathbf{6}$ were studied in toluene, chloroform, acetonitrile, DMSO, and methanol. Relative fluorescence quantum yields were measured using Coumarin 1 in ethanol $\left(\Phi_{\mathrm{f}}=73 \%{ }^{[28]}\right)$ as a reference. Selected spectral data are given in Table 1 .

All the products absorb on the border of the UV and visible regions, and demonstrate green or yellow fluorescence. At that, the compounds comprising dimethylaminobenzylidene terminal group (3a, 5a) possess a substantial positive solvatochromism. Solvatochromic shifts of dyes $\mathbf{3 b}$ and $\mathbf{5 b}$ are feeble and depend irregularly on solvent polarity, what can be rationalized taking into account polyenic (low 


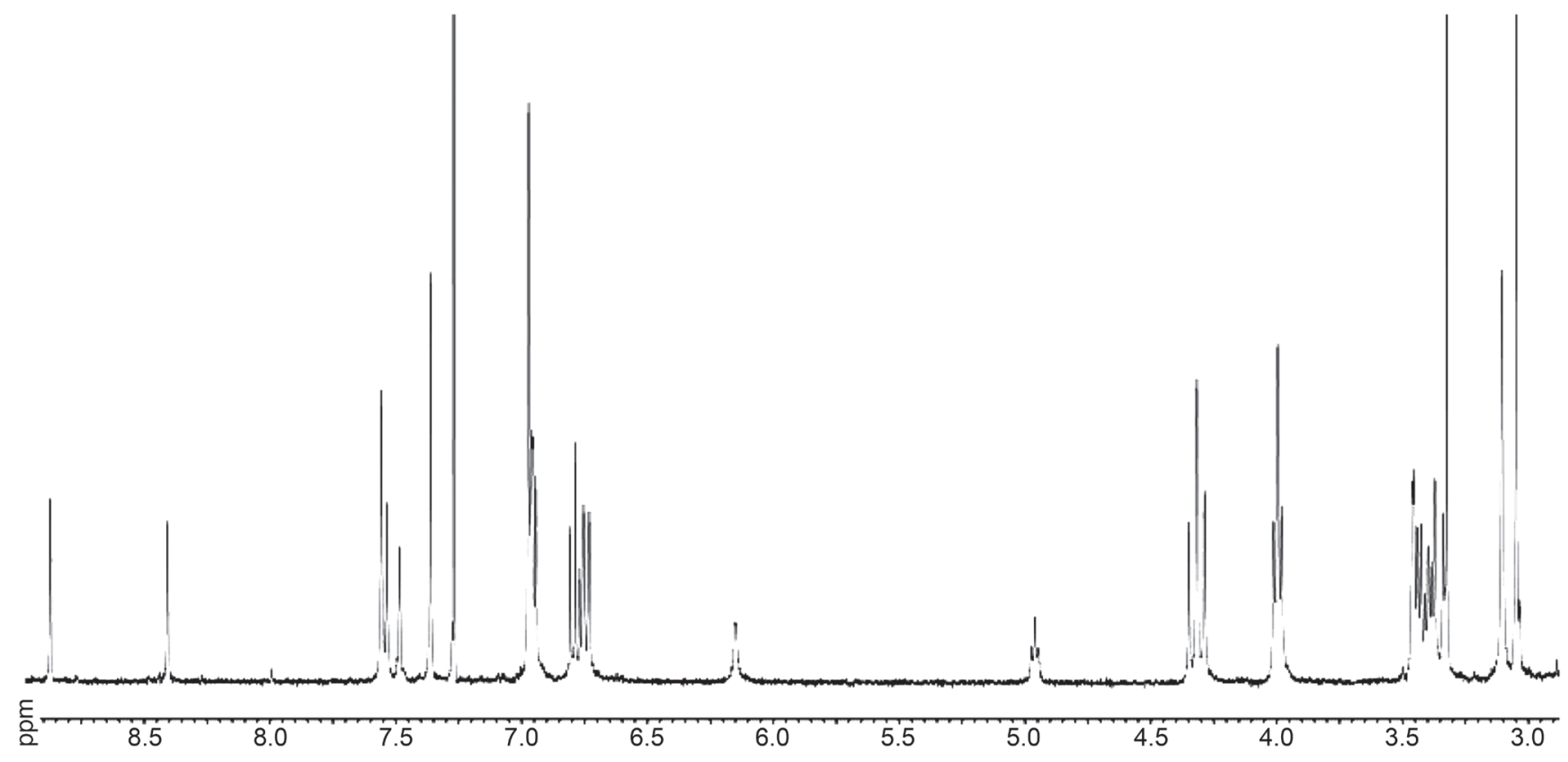

Figure 2. Representative section of ${ }^{1} \mathrm{H}$ NMR spectrum of 5a in $\mathrm{CDCl}_{3}$.

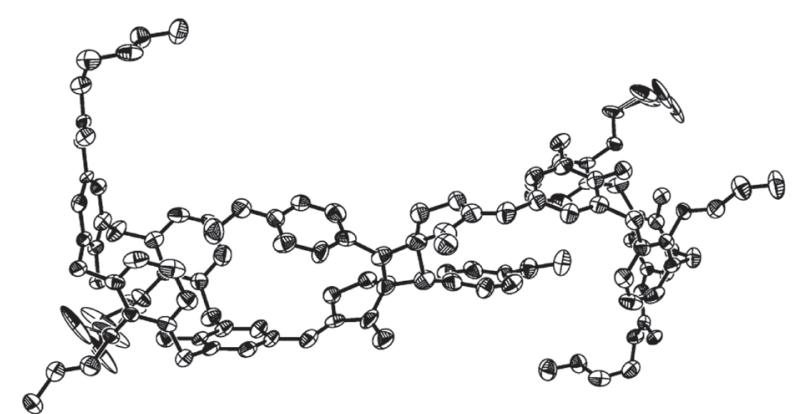

Figure 3. Centrosymmetrical dimer of $\mathbf{5 b}$ in crystal phase. $\mathrm{H}$-atoms are omitted for clarity. Thermal ellipsoids are shown at the $50 \%$ probability level.

polar) character of the ground state of ketocyanines without strong electron-donating moieties in their chromophore. At the same time all the compounds possess strong positive solvatofluorochromism typical for ketocyanine dyes (Table 1 and Figure 4).

Equivalence of the fluorophore unit in compounds $\mathbf{3 b}$, $\mathbf{5 b}$, and $\mathbf{6}$ allowed us to study the differences in solvation of carbonyl oxygen of the ketocyanine unit in calixarene derivatives and model compound 6 (see Table 1, data in $\mathrm{CHCl}_{3}$ and $\mathrm{MeOH}$ and SI file). In all cases the presence of calixarene core gives a $10-20 \mathrm{~nm}$ red shift of the absorption and fluorescence maxima. The highest values of the shift are observed for the fluorescence of the calixarene based compounds in polar DMSO or $\mathrm{MeOH}$. This effect displays a solvent-mediated influence of the remote polar group on the electronic state of ketocyanine fluorophore and demonstrate clearly the possibility of control of fluorescence colour by varying the nature of the analyte bound in the proximity to the fluorophore unit.
Table 1. UV-Vis and fluorescent spectral characteristics of compounds 3a,b, 5a,b, and $\mathbf{6}$ measured in solvents of various polarity at $20^{\circ} \mathrm{C}$.

\begin{tabular}{|c|c|c|c|c|c|}
\hline Comp. & Solvent & $\begin{array}{c}\lambda_{\max }^{\text {abs }} \\
(\mathrm{nm})\end{array}$ & $\begin{array}{l}\lambda_{\text {max }}^{\mathrm{fl}} \\
(\mathrm{nm})\end{array}$ & $\begin{array}{l}\Phi_{\mathrm{f}} \\
(\%)\end{array}$ & $\begin{array}{c}\mathrm{SS} \\
\left(\mathrm{cm}^{-1}\right)\end{array}$ \\
\hline \multirow[t]{5}{*}{$3 a$} & $\mathrm{PhCH}_{3}$ & 442 & 492 & 0.8 & 2300 \\
\hline & $\mathrm{CHCl}_{3}$ & 448 & 538 & 4.8 & 3730 \\
\hline & $\mathrm{MeCN}$ & 440 & 582 & 5.0 & 5550 \\
\hline & DMSO & 451 & 594 & 5.6 & 5340 \\
\hline & $\mathrm{MeOH}$ & 456 & 602 & 0.5 & 5320 \\
\hline \multirow[t]{3}{*}{$3 b$} & $\mathrm{PhCH}_{3}$ & 398 & 448 & $<0.1$ & 2800 \\
\hline & $\mathrm{CHCl}_{3}$ & 401 & 476 & 0.5 & 3930 \\
\hline & $\mathrm{MeOH}$ & 402 & 521 & 0.3 & 5680 \\
\hline \multirow[t]{5}{*}{$5 a$} & $\mathrm{PhCH}_{3}$ & 442 & 491 & 0.6 & 2260 \\
\hline & $\mathrm{CHCl}_{3}$ & 450 & 537 & 5.0 & 3600 \\
\hline & $\mathrm{MeCN}$ & 441 & 582 & 5.6 & 5490 \\
\hline & DMSO & 453 & 593 & 6.7 & 5210 \\
\hline & $\mathrm{MeOH}$ & 459 & 604 & 1.5 & 5230 \\
\hline \multirow[t]{3}{*}{$5 b$} & $\mathrm{PhCH}_{3}$ & 398 & 440 & $<0.1$ & 2400 \\
\hline & $\mathrm{CHCl}_{3}$ & 404 & 478 & 0.5 & 3830 \\
\hline & $\mathrm{MeOH}$ & 403 & 511 & 0.3 & 5240 \\
\hline \multirow[t]{2}{*}{6} & $\mathrm{CHCl}_{3}$ & 384 & 462 & 0.03 & 4400 \\
\hline & $\mathrm{MeOH}$ & 393 & 497 & 0.8 & 5320 \\
\hline
\end{tabular}

$\lambda_{\text {max }}^{\text {abs }}$-absorption maximum; $\lambda_{\text {max }}^{\mathrm{fl}}$ - fluorescence maximum; $\Phi_{\mathrm{f}}$ - fluorescence quantum yield; SS - Stokes' shift.

The polarization of chromophore unit provide a regular increase of Stokes' shifts with increasing solvent polarity. The fluorescence quantum yields, while relatively small, are several times higher for the calixarene ketocyanines than for the model compound $\mathbf{6}$, showing the spatial influence of the rigid calixarene skeleton on the fluorescence properties. 


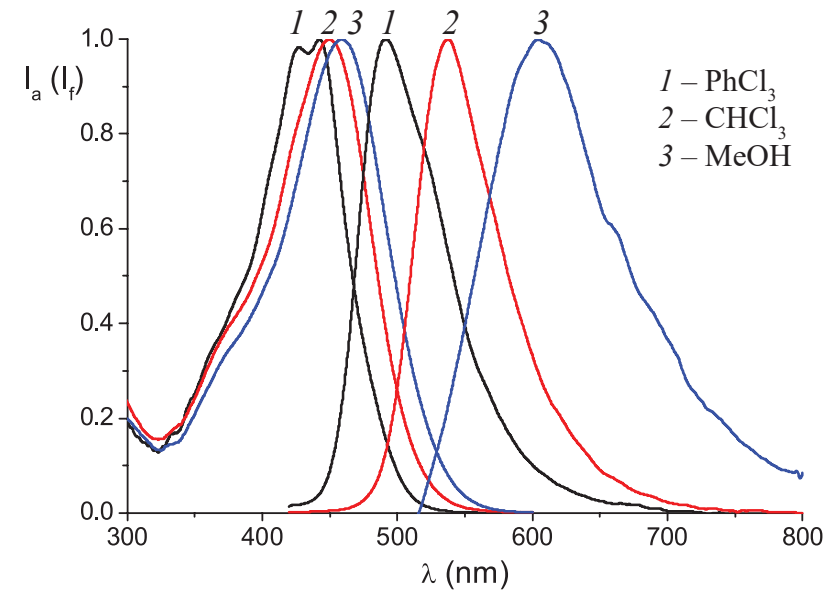

Figure 4. Normalized UV-Vis and fluorescent spectra of compound $\mathbf{5} \mathbf{a}$ in toluene, $\mathrm{CHCl}_{3}$, and $\mathrm{MeOH}$.

To evaluate photochemical stability of calixarene ketocyanines, the $1.2 \cdot 10^{-5} \mathrm{M}$ solution of compound $\mathbf{5 a}$ in DMSO was subjected to UV irradiation (250 W laboratory UV lamp, $1 \mathrm{~cm}$ quartz cuvette, sample-to-lamp distance circa $40 \mathrm{~cm}$ ). Absorption spectra of the tested solution of $\mathbf{5 a}$ after $3 \mathrm{hr}$ of irradiation proved its relatively low photochemical stability - the solution retained only $60 \%$ of its initial optical density at the absorption maximum.

\section{Conclusions}

In summary, the synthetic approaches to calix[4]arene ketocyanines functionalized with nitro-, amino- or urea moieties at the wide macrocycle rim were elaborated. The UV-Vis and fluorescence studies have been carried out for the compounds synthesized. The estimated solvatofluorochromism levels and quantum yield values demonstrate clearly a possibility of control of fluorescence colour and intensity by varying the nature of the analyte bound in the proximity of the fluorophore unit.

Acknowledgements. This work was supported by the NAS of Ukraine through the grant "Chemosensor system such as "electronic nose" for biomedical and of environmental application". The authors thank Mr. O. Dukhno for experimental assistance.

\section{References}

1. Demchenko A.P. Introduction to Fluorescence Sensing $\left(2^{\text {nd }} \mathrm{ed}\right)$, Dordrecht: Springer, 2015. 794 p.
2. Kim S.H., Kim H.J., Yoon J., Kim J.S. Calixarenes in the Nanoworld (Vicens J., Harrowfield J., Eds.), Dordrecht: Springer, 2007, Ch. 15, p. 311-333.

3. Chemosensors of Ion and Molecule Recognition (Desvergne J.-P., Czarnik A.W., Eds.), NATO Science Series C, Dordrecht: Kluwer Academic, 1997, 268 p.

4. Hesse J., Sonnleitner M., Sonnleitner A., Freudenthaler G., Jacak J., Höglinger O., Schindler H., Schütz G.J. Anal Chem. 2004, 76, 5960-5964.

5. Fabbrizzi L., Poggi A. Chem. Soc. Rev. 1995, 197-202.

6. Valeur B., Bourson J., Pouget J., Czarnik A.W. In: Fluorescent Chemosensors for Ion and Molecule Recognition, ACS Symposium Series 538, Washington DC: American Chemical Society, 1993. p. 25-44.

7. Tan W., Shi Z.Y., Kopelman R. Anal. Chem. 1992, 64, 29852990.

8. Sharp S.L., Warmack R.J., Goudonnet J.P., Lee I., Ferrell T.L. Acc. Chem. Res. 1993, 26, 377-382.

9. Gutsche C.D. Calixarenes Revisited. Monograph in Supramolecular Chemistry (Stoddart J.F., Ed.), Cambridge: Royal Society of Chemistry, 1998, $248 \mathrm{p}$

10. Calixarenes 2001 (Asfari Z., Böhmer V., Harrowfield J.M., Vicens J., Eds.) Dordrecht: Kluwer Academic, 2001, 694 p.

11. Yoon K., Kim K. J. Org. Chem. 2005, 70, 427-432.

12. He H., Mortellaro M.A, Leiner M.J.P., Fraatz R.J., Tusa J.K. J. Am. Chem. Soc. 2003, 125, 1468-1469.

13. Lee J., Kim S.K., Jung J.H., Kim J.S. J. Org. Chem. 2005, 70, $1463-1466$.

14. Seneque O., Rager M.N., Giorgi M., Reinaud O. J. Am. Chem. Soc. 2000, 122, 6183-6189.

15. Gordon A.J., Ford R.A. The Chemist's Companion. A Handbook of Practical Data Techniques and References, New York: Wiley, 1972, $537 \mathrm{p}$.

16. Sheldrick G.M. Acta Crystallogr., Sect. A 2008, A64, 112.

17. Matvieiev Yu., Karpenko Iu., Kulinich A., Ryabitskii O., Pivovarenko V., Shishkina S., Shishkin O., Kalchenko V. Tetrahedron Lett. 2011, 52, 3922-3925.

18. Arduini A., Fabbi M., Mantovani M., Miron, L., Pochini A., Secchi A., Ungaro R. J. Org. Chem. 1995, 60, 1454-1457.

19. Vatsadze S.Z., Sviridenkova N.V., Manaenkova M.A., Semashko V.S., Zyk N.V. Russ. Chem. Bull. 2005, 54, 2224 2225.

20. Kreher U.P., Rosamilia A.E., Raston C.L., Scott J.L., Strauss C.R. Org. Lett. 2003, 5, 3107-3110.

21. Jaime C., de Mendoza J., Prados P., Nieto P.M., Sanchez C. J. Org. Chem. 1991, 56, 3372-3376.

22. Margans J.O., de Mendoza J., Pons M., Prados P. J. Org. Chem. 1997, 62, 4518-4520.

23. Casnati A., Fochi M., Minari P., Pochini A., Reggiani M., Ungano R., Reinhoudt D.N. Gazz. Chim. Ital. 1996, 126, 99-106.

24. Gale P.A. Coord. Chem. Rev. 2003, 240, 191-221.

25. Beer P.D., Gale P.A. Angew. Chem. Int. Ed. 2001, 40, 486-516.

26. Matvieiev Yu., Dukhno O., Ryabitskii O., Shishkina S., Shishkin O., Pivovarenko V., Kalchenko V. Pat. Ukraine N83416. 2013, Bull. N17.

27. Schmidt G.M.J. Pure Appl. Chem. 1971, 27, 647.

28. Jones II G., Jackson W.R., Choi C., Bergmark W.R. J. Phys. Chem. 1985, 89, 294-300. 